\title{
Cladotanytarsus crassus, a new North American non-biting midge with a distinctive hypopygial digitus (Diptera: Chironomidae)
}

\author{
WoJCIECH GiŁKA*, MATEUSZ PUCHALSKI
}

University of Gdańsk, Faculty of Biology, Department of Invertebrate Zoology and

Parasitology, Wita Stwosza 59, 80-308 Gdańsk, Poland

\begin{abstract}
Cladotanytarsus (Cladotanytarsus) crassus sp. n. is described from the USA (Oregon, Wyoming) and Canada (Ontario). The distinctive structure of the adult male hypopygium, bearing a thickset digitus and a stout elongated superior volsella, is presented. Intraspecific morphological variations are described in order to compare $C$. crassus and C. nigrovittatus (GOETGHEBUER, 1922), treated as close relatives. The geographical distribution and ecology of the two species are commented on.
\end{abstract}

KEY WORDS: Diptera, Chironomidae, Tanytarsini, taxonomy, new species, biogeography.

\section{INTRODUCTION}

The male genital apparatus (hypopygium) in chironomids displays an enormous morphological diversity that is of prime importance in species delimitation and systematics. In some Chironomidae subfamilies the hypopygium evolved towards morphological complexity, reaching its highest level in several young groups. With three or four pairs of hypopygial appendices (incl. 3 pairs of volsellae), non-biting midges of the subfamily Chironominae and the tribe Tanytarsini are known as bearers of the most complex hypopygia. They are both the oldest fossil tribe representatives (e.g. GIEKA et al. 2013, ZAKRZEWSKA \& GIŁKA 2014, ZAKRZEWSKA et al. 2016, 2018) and the extant Tanytarsini of two known subtribes: the Zavreliina (e.g. GILKA 2005, EKREM 2007, EKREM \& STUR 2009)

\footnotetext{
* Corresponding author: wojciech.gilka@biol.ug.edu.pl
} 
and the Tanytarsina (e.g. REISS \& SÄWEDAL 1981, KYEREMATEN \& SÆTHER 2000, EKREM 2001, EKREM et al. 2003, SANSEVERINO 2006, STUR \& EKREM 2006, GIKA \& PAASIVIRTA 2007, DANTAS \& GIŁKA 2017, LIN et al. 2017). The fourth hypopygial appendix is defined as the inner apical finger of the superior volsella, called the digitus (SÆTHER 1980). The digitus clearly evolved independently within the subtribe Tanytarsina, either towards reduction or, more often, being developed into a process of sophisticated shape and/or a lobe distinctly enlarged in several genera, groups or species (op. cit.). Such a welldeveloped digitus is one of the most distinctive characters in the genus Cladotanytarsus KIEFFER, 1921. With few exceptions (e.g. C. teres HIRVENOJA, 1962), the digitus is long, extends far beyond the apex of the superior volsella and usually has a swollen finger-like tip or is covered with serrations (GIEKA 2011a, 2011b). In the new species presented below, the digitus is uncommonly large, and together with a stout elongated superior volsella forms a character combination unknown in other species of the genus. Cladotanytarsus has a worldwide distribution: so far, 79 species have been described, including 22 species recorded from the Nearctic region (SÆTHER 1971, BILYJ \& DAVIES 1989, GIŁKA 2011b, PUCHALSKI \& GILKA 2017a, 2017b, PUCHALSKI et al. 2017, 2018).

\section{MATERIALS AND METHODS}

The specimens examined were collected using a sweep net and slide-mounted in Canada balsam. Measurements are in $\mu \mathrm{m}$; the lengths of leg segments and palpomeres have been rounded off to the nearest 5 and $1 \mu \mathrm{m}$ respectively; the antennal, leg and venarum ratios (AR, LR, VR) have been calculated to the second decimal place. The morphological terminology and abbreviations follow SÆTHER (1980). The photographs were taken using a Leica DM6000 microscope and LAS Montage multifocus; the drawings were prepared using the technique by GIKA (2008). The type material, collected from Canada and the USA (the collection of M. \& J.E. SUBLETTE) is booked to be deposited at the Department of Entomology, the University of Minnesota Insect Collection, St. Paul, USA. The other specimens examined are housed in the Department of Invertebrate Zoology and Parasitology, University of Gdańsk, Poland. 


\section{RESULTS}

Family: Chironomidae NEWMAN, 1834

Subfamily: Chironominae NewMAN, 1834

Tribe: Tanytarsini ZAVŘEL, 1917

Subtribe: Tanytarsina ZAVŘEL, 1917

Genus: Cladotanytarsus KIEFFER, 1921

Subgenus: Cladotanytarsus s. str. KIEFFER, 1921

\section{Cladotanytarsus (Cladotanytarsus) crassus sp. n.}

Figs 1A, 2, 3A, 4A

\section{Type material}

Holotype, adult male: USA, OREGON, Douglas Co., Diamond Lake $\left(43^{\circ} 09^{\prime} \mathrm{N}\right.$ $\left.122^{\circ} 09^{\prime} \mathrm{W}\right), 4$ August 1966, J. WILCOX. Paratypes: 15 males as holotype; WYOMING, Teton Co., Yellowstone Lake, Bridge Bay $\left(44^{\circ} 32^{\prime} \mathrm{N} 110^{\circ} 26^{\prime} \mathrm{W}\right), 27$ June 1952, 1 male hypopygium, J.E. SUBLETTE; CANADA, ONTARIO, White Lake near Ottawa $\left(45^{\circ} 21^{\prime} \mathrm{N}\right.$ 76³0'W), 29 June 1968, 2 males, R.D. MCDONALD.

\section{Derivation of the name}

The specific name, derived from the Latin word meaning bulky, refers to the robust hypopygial digitus.

\section{Diagnosis}

Anal point elongated, more or less lanceolate, usually with nipple-like tip. Superior volsella stout and elongated, evenly tapering towards blunt or horn-shaped apex, bearing dense microtrichia on 2/3 proximal surface dorsally. Digitus extending far beyond superior volsella, robust, parallel-sided or with hump at half-length, slightly swollen distally, apex rounded. Stem of median volsella with 4-6 furcate lamellae; stem and lamellae of similar length.

\section{Description}

Adult male $(\mathrm{n}=18$ specimens +1 male hypopygium $)$

Colouration. Eyes black. Antennal pedicel, tentorium, scutal stripes, scutellum, postnotum and sternum dark brown. Antennal flagellum, legs and abdomen olive green to brown. Head capsule, mouthparts, ground colour of thorax and haltere pale brown with greenish undertone. Wing transparent. 


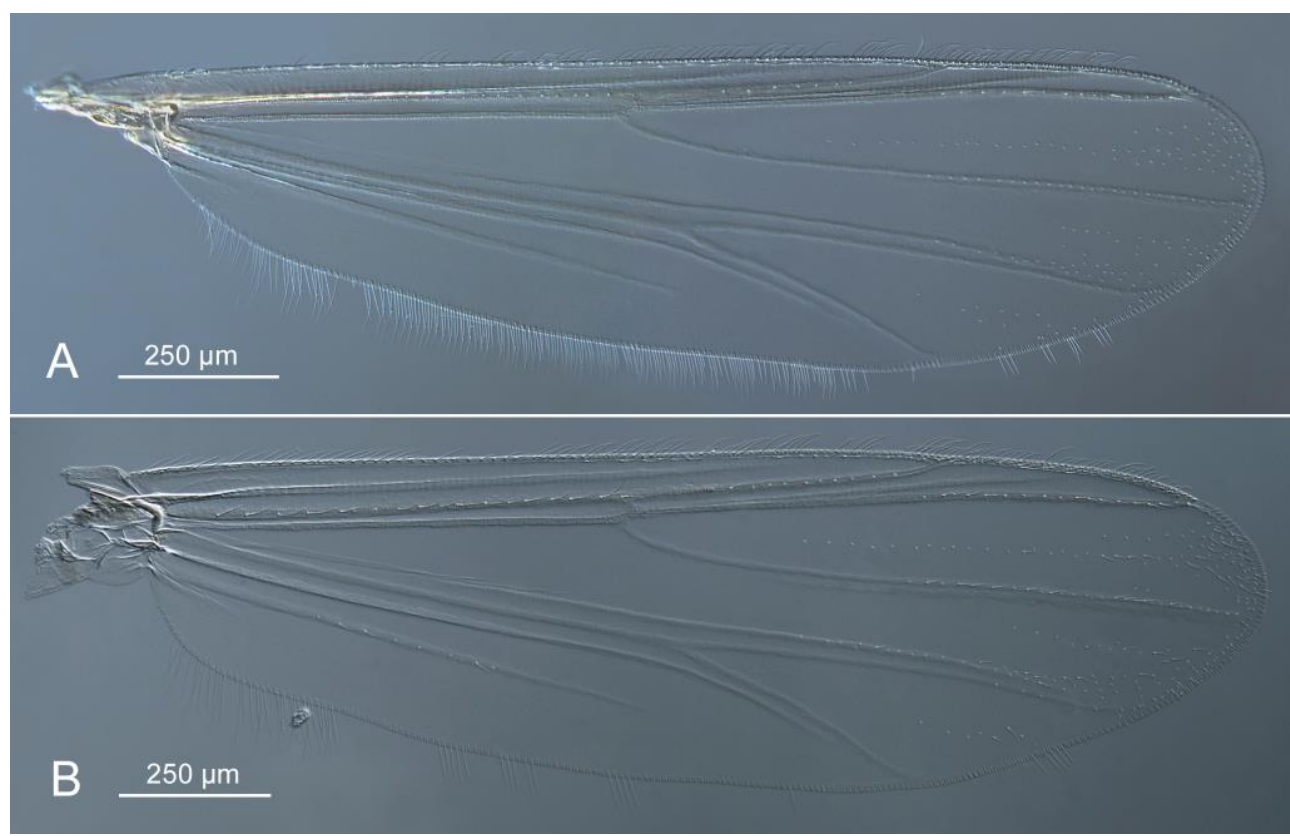

Fig. 1. Wing of male. A - Cladotanytarsus (Cladotanytarsus) crassus sp. n., B - Cladotanytarsus (Cladotanytarsus) nigrovittatus (GOETGHEBUER, 1922).

Head. Eyes reniform, broadly separated. Antenna with 13 flagellomeres, AR 0.96-1.21 (1.07), plume fully-developed. Frontal tubercles conical, up to $15 \mu \mathrm{m}$ long and $5 \mu \mathrm{m}$ wide at base. Lengths of palpomeres 2-5 (in $\mu \mathrm{m}$ ): 31-41 (34), 92-113 (102), 87-108 (97), 110-177 (151); $\mathrm{pm}_{3}>\mathrm{pm}_{4}(\mathrm{n}=11)$ or $\mathrm{pm}_{3} \leq \mathrm{pm}_{4}(\mathrm{n}=4)$. Clypeus with 10-20 setae.

Thorax chaetotaxy. Ac 4-6; Dc 4-10 usually 6 or 7 on each side; Pa 1 on each side; Scts 2-4 usually 2.

Wing. Length 1550-1765 (1675) $\mu \mathrm{m}$. Venation pattern and chaetotaxy typical of the genus as shown in Fig. 1A. Veins $C, R$, middle section of $R_{1}$, distal half of $R_{4+5}$ and $M_{1+2}$, and apical section of false vein above $\mathrm{M}_{3+4}$ with macrotrichia, An rarely with 1-3 macrotrichia $(\mathrm{n}=4), \mathrm{Cu}_{1}$ exceptionally with macrotrichia $(\mathrm{n}=1)$, other veins bare; membrane with macrotrichia placed in row at 3/4 length of $r_{4+5}$ and in distal area of $r_{4+5}$, $\mathrm{m}_{1+2}$ and $\mathrm{m}_{3+4}$ other cells bare. VRCu 1.10-1.29 (1.20).

Legs. Fore leg tibia with straight spur ca. $5 \mu \mathrm{m}$ long. Combs of mid and hind leg tibiae separated, spurs straight or longer spur slightly curved at apex: 10-20 $\mu \mathrm{m}$ long on mid leg and 20-35 $\mu \mathrm{m}$ long on hind leg. Basitarsus of mid leg with 2-3 sensilla chaetica. Lengths of leg segments and leg ratios as shown in Table 1. 


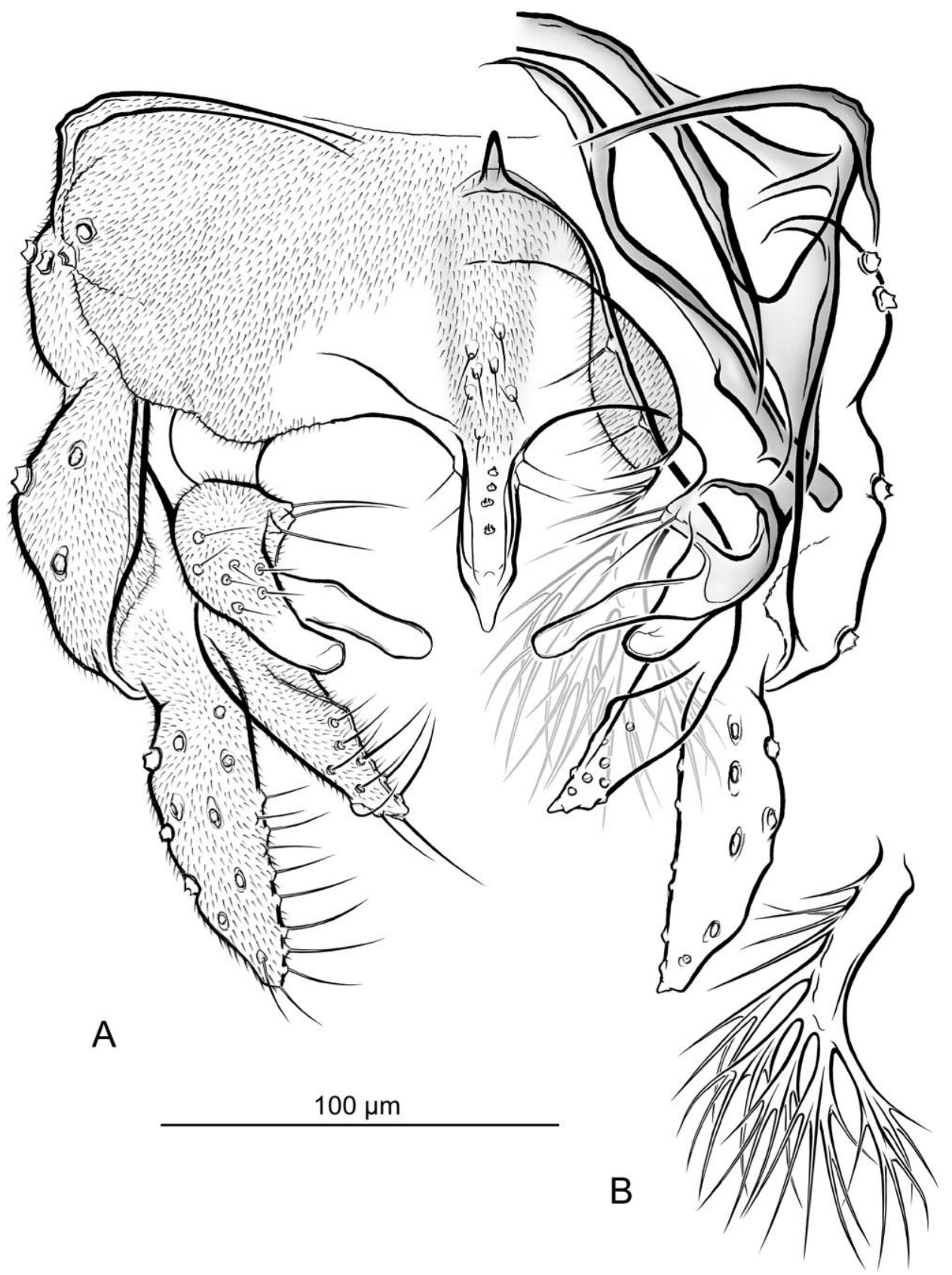

Fig. 2. Cladotanytarsus (Cladotanytarsus) crassus sp. n., male. A - hypopygium, B - median volsella. 


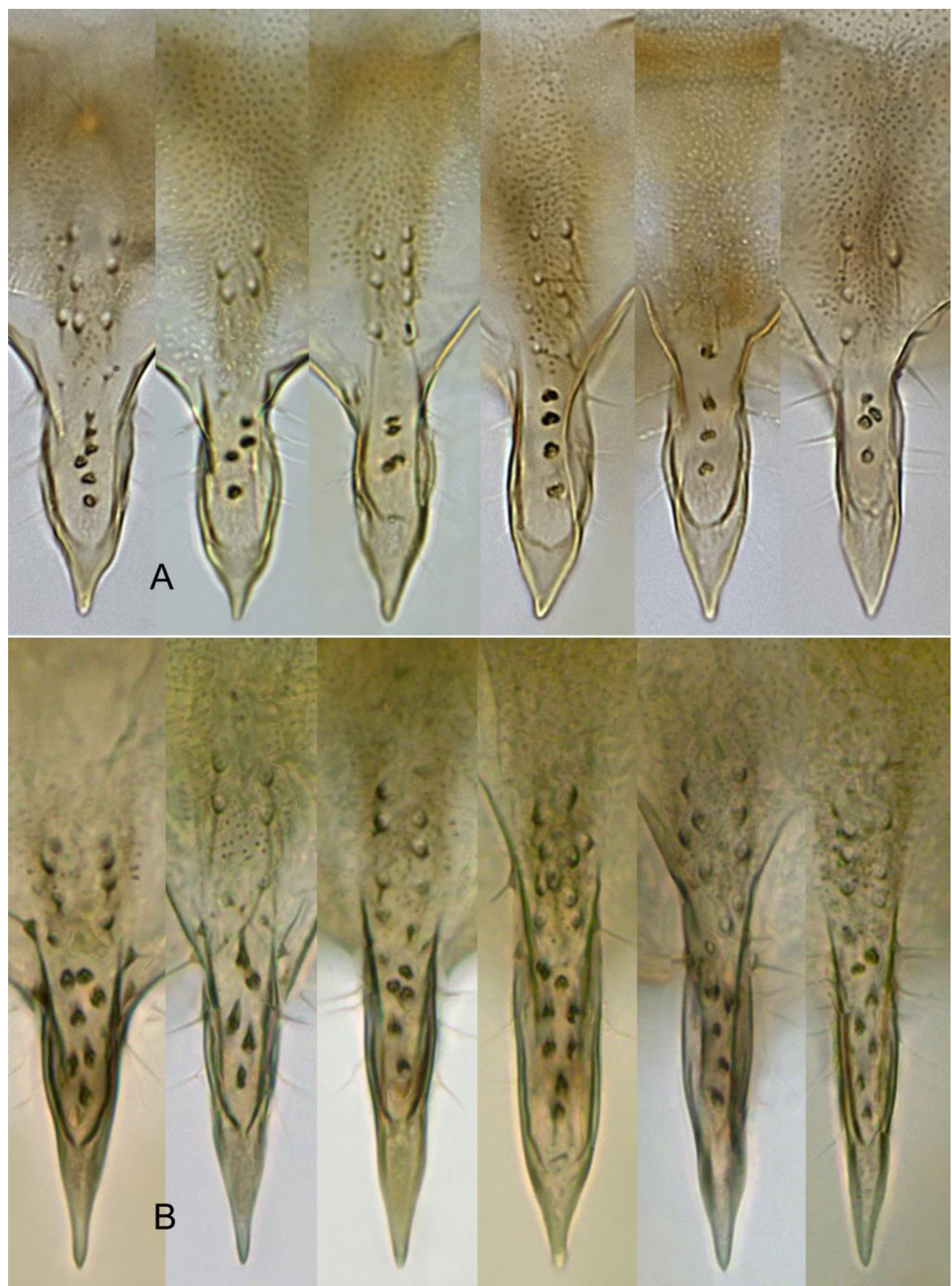

Fig. 3. Hypopygial anal point, variations. A - Cladotanytarsus (Cladotanytarsus) crassus sp. n., B - Cladotanytarsus (Cladotanytarsus) nigrovittatus. 


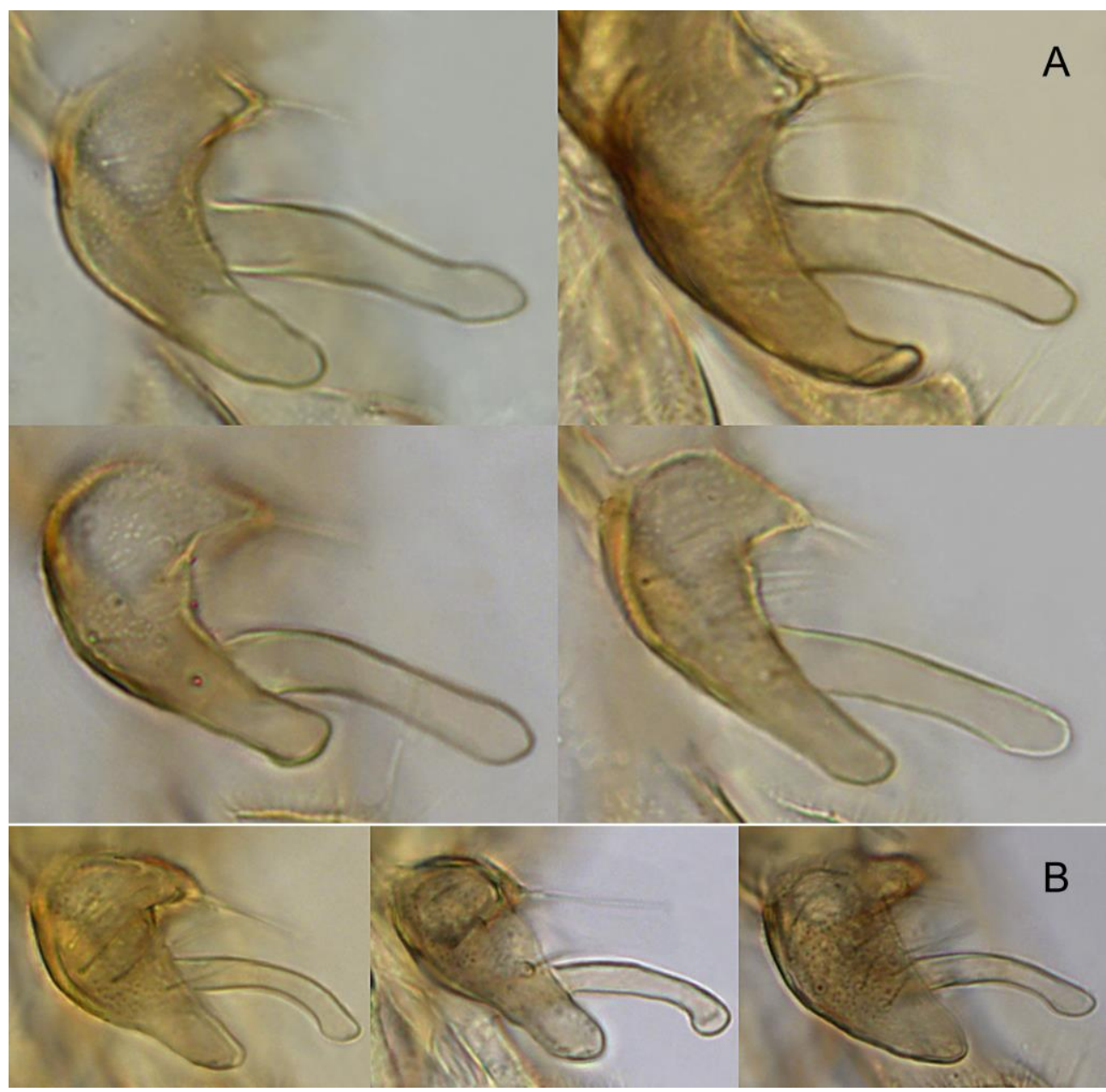

Fig. 4. Hypopygial superior volsella and digitus, variations. A - Cladotanytarsus (Cladotanytarsus) crassus sp. n., B - Cladotanytarsus (Cladotanytarsus) nigrovittatus.

Hypopygium (Figs 2-4). Gonostylus shorter than gonocoxite, 70-100 (85) $\mu \mathrm{m}$ long. Phallapodeme distinctly broadened in anterior section. Anal tergite with V-type separated bands, 1-2 lateral setae on each side, 4-11 (7) median setae placed in two rows or arranged irregularly, and with extensive microtrichia-free area at base of anal point (Fig. 2A). Anal point elongated, lanceolate, broadened at mid length, usually with nipple-like tip, slightly variable in shape as shown in Figs 3A; 2-6 (4) spinulae arranged in more or less regular row between prominent crests. Superior volsella stout and elongated, rounded at base, narrowed in middle part, evenly tapering towards blunt or horn-shaped apex, bearing 4-7 
(5) dorsal setae and dense microtrichia covering $2 / 3$ proximal surface dorsally; digitus extending far beyond superior volsella, robust, parallel-sided or with hump at half-length, slightly swollen distally, apex rounded (Figs 2A, 4A). Stem of median volsella 35-45 (40) $\mu \mathrm{m}$ long, slightly curved, bearing several setiform and 4-6 furcate lamellae; stem and lamellae of similar length (Fig. 2B). Inferior volsella slender, with knee-like extension at base, prominent angular dorsomedian ridge and narrow pointed apex (Fig. 2A).

Table 1. Leg segment lengths $(\mu \mathrm{m})$ and leg ratios of male Cladotanytarsus (Cladotanytarsus) crassus sp. $\mathrm{n}$.

\begin{tabular}{ccccccccc}
\hline & $\mathrm{fe}$ & $\mathrm{ti}$ & $\mathrm{ta}_{1}$ & $\mathrm{ta}_{2}$ & $\mathrm{ta}_{3}$ & $\mathrm{ta}_{4}$ & $\mathrm{ta}_{5}$ & $\mathrm{LR}$ \\
\hline $\mathrm{p}_{1}$ & $635-760$ & $390-460$ & $670-800$ & $370-450$ & $290-350$ & $210-245$ & $115-135$ & $1.66-1.95$ \\
& $(705)$ & $(430)$ & $(755)$ & $(415)$ & $(320)$ & $(225)$ & $(120)$ & $(1.76)$ \\
& $695-790$ & $535-650$ & $310-400$ & $195-230$ & $145-205$ & $105-125$ & $70-105$ & $0.53-0.58$ \\
$\mathrm{p}_{2}$ & $(750)$ & $(610)$ & $(345)$ & $(210)$ & $(160)$ & $(110)$ & $(90)$ & $(0.55)$ \\
& $780-860$ & $760-880$ & $480-545$ & $330-380$ & $265-295$ & $185-205$ & $115-125$ & $0.72-0.81$ \\
$\mathrm{p}_{3}$ & $(820)$ & $(840)$ & $(520)$ & $(360)$ & $(285)$ & $(195)$ & $(120)$ & $(0.77)$ \\
\hline
\end{tabular}

Table 2. Comparison of diagnostic characters in male Cladotanytarsus (Cladotanytarsus) crassus sp. n. and C. (Cladotanytarsus) nigrovittatus.

\begin{tabular}{|c|c|c|}
\hline Character / species & C. crassus & C. nigrovittatus \\
\hline Tentorium & dark brown & transparent, greenish \\
\hline Phallapodeme & anterior section broad & anterior section narrow \\
\hline Anal point & $\begin{array}{c}\text { lanceolate, broadened at mid length, } \\
\text { usually with nipple-like tip }\end{array}$ & $\begin{array}{c}\text { subtriangular, narrow, } \\
\text { evenly tapering towards pointed tip }\end{array}$ \\
\hline Digitus & robust, parallel-sided, apex rounded & slender, apex swollen finger-like \\
\hline Digitus / SVo apices & $\begin{array}{c}\text { equally sized or digitus apex } \\
\text { broader than SVo apex }\end{array}$ & $\begin{array}{c}\text { digitus apex never as broad as SVo } \\
\text { apex }\end{array}$ \\
\hline MVo stem/lamellae & stem and lamellae of similar length & stem distinctly longer than lamellae \\
\hline
\end{tabular}

\section{Comments}

The main metric characters, the wing venation pattern, the thorax chaetotaxy, the elongated hypopygial anal point and digitus, and the setation of the anal tergite and superior volsella indicate that Cladotanytarsus crassus and $C$. nigrovittatus are closely related. The two species differ, however, as shown in Figures $3 \& 4$ and Table 2. Because of the median 
volsella stem/lamellae length proportions, $C$. crassus falls into the couplet 5 of the key given by PUCHALSKI and GIŁKA (2017a), otherwise directing to couplets 13-15 for $C$. muricatus BILYJ, 1989, C. bilyji GIKA \& PUCHALSKI, 2017 and C. nigrovittatus.

All records of Cladotanytarsus crassus adults come from the surroundings of lakes, which suggests that the larvae of this species are limnophilous or limnobiontic.

\section{Cladotanytarsus (Cladotanytarsus) nigrovittatus (GOETGHEBUER, 1922)}

Figs 1B, 3B, 4B

Tanytarsus nigrovittatus GOETGHEBUER, 1922: 41 (male, Belgium).

Cladotanytarsus mancus: BRUNDIN 1947: 80 (male, Sweden); HIRVENOJA 1962: 180 (male, pupa; Finland).

Cladotanytarsus nigrovittatus: LINDEBERG 1964: 74 (male, pupa; Finland); Oliver \& Dillon 1997: 625 (Canada); MAZUMdaR et al. 2000: 196 (male, India); GIEKA 2001: 319 (male, Poland); GıKA 2002: 419, 421 (Poland); WANG \& GuO 2004: 8 (male, China); MAKARCHENKO et al. 2005: 413 (Russian Far East); GiŁKA 2011a: 63 (male, Poland); GIŁKA 2011c: 18 (Europe); RUSE 2015: 83 (Poland); PUCHALSKI \& GIŁKA 2017a: 355 (male; Finland, Poland, Sweden).

\section{Material examined (new records)}

FINLAND: Äänekoski (N62³6'10" E2541'43"), 12 July 2002, 1 male; Hietajärvi (N66 $30^{\prime} 43^{\prime \prime}$ E28 $\left.20^{\prime} 00^{\prime \prime}\right), 1$ August 2002, 3 males; Inari-Pappila (N68 $54^{\prime} 26^{\prime \prime}$ E2701'54"), 17 July 2002, 1 male; Inari-Vuopajanniemi (68 $\left.54^{\prime} 37^{\prime \prime N} 27^{\circ} 01^{\prime} 44^{\prime \prime E}\right), 4$ August 2003, 2 males; Lake Keitele (N62 $48^{\prime} 34^{\prime \prime}$ E25 $\left.5^{\circ} 48^{\prime} 26^{\prime \prime}\right), 12$ July 2002, 1 male; Kemijoki near

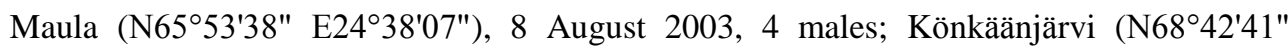
E2750'04"), 20 July 2003, 4 males; Korvala (N66 $53^{\prime} 53^{\prime \prime}$ E26 $6^{\circ} 11^{\prime} 48^{\prime \prime)}, 14$ July 2002, 5 males; Kotka-Mussalo (N60²6'10" E26 $\left.6^{\circ} 2^{\prime} 00^{\prime \prime}\right), 5$ August 2002, 7 males; LemmenjokiNjurgalahti (N68 45'31" E26 $\left.14^{\prime} 03^{\prime \prime}\right), 27$ July 2002, 12 males; Menesjärvi (N68 $43^{\prime} 46^{\prime \prime}$

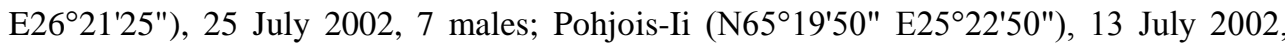
1 male; Puruvesi (N61 $50^{\prime} 35^{\prime \prime}$ E29 $\left.9^{\circ} 44^{\prime} 00^{\prime \prime}\right), 5$ August 2002, 2 males; Simpelejärvi (N6127'46" E29²6'53"), 5 August 2002, 6 males; Solojärvi (N6849'49" E26²6'33"), 4 August 2003, 2 males; Syysjärvi (N69 $16^{\prime} 32^{\prime \prime}$ E27¹1'39"), 26 July 2003, 4 males; Tervola (N66 $05^{\prime} 03^{\prime \prime}$ E244 $\left.47^{\prime 2} 8^{\prime \prime}\right), 22$ July 2003, 4 males, 19 July 2006, 1 male; Tuurujärvi

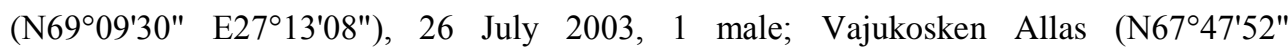

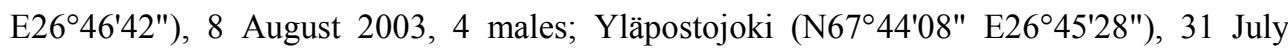
2002, 1 male; all specimens collected by W. GIEKA. POLAND: Ocypel (N534' $55^{\prime \prime}$

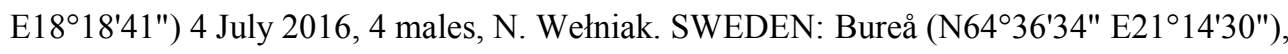


9 August 2003, 5 males; Emådalen (N61 $21^{\prime} 13^{\prime \prime}$ E14 $\left.45^{\prime} 14 "\right)$, 19 July 2003, 1 male; Kalix

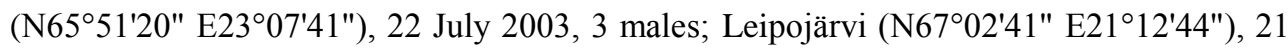
July 2003, 2 males; Ljusnan (N6202'55" E14³8'19"), 19 July 2003, 1 male; Räktjärv

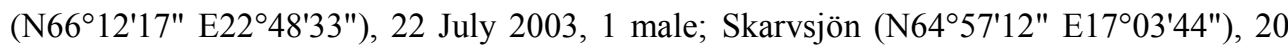
July 2003, 4 males; Stenträsk (N66 20'02" E1949'52"), 21 July 2003, 2 males; all specimens collected by W. GıKA. For other records from Finland, Poland and Sweden see GIEKA (2001, 2002), RUSE (2015), and PUCHALSKI and GIEKA (2017a).

\section{Comments}

A brief analysis of frequency and abundance, based on all the available materials examined here, indicates that Cladotanytarsus nigrovittatus is one of the most common Tanytarsini species in northern Europe. Among over 6400 Tanytarsini males ( 83 species) collected using a sweep net from 95 sites in Finland and Sweden in 2002-2006, 507 specimens of C. nigrovittatus (ca. 8\%) were taken from 39 sites. In contrast, among over 6600 Tanytarsini males (106 species) collected using a sweep net, light, Malaise, Moericke and glue traps from 146 sites in Poland over a period of 43 years (1974-2016), only 73 individuals of $C$. nigrovittatus (ca. 1\%) were sampled from 7 sites (the present senior author's inventory). These results clearly indicate that $C$. nigrovittatus is much more frequent and abundant in northern Europe, and presumably throughout the northern Palaearctic as well ( $c f$. WANG \& GUO 2004, MAKARCHENKO et al. 2005), although the species is rarely reported from North America. OLIVER \& DiLlon (1997) recorded C. nigrovittatus from Trout Lake (Yukon) and identified it as a circumpolar species. Barcodes of several specimens from the Prince Albert National Park (Saskatchewan) are available in the BoldSystems and GenBank data bases. A few further specimens from Bare Lake (Alaska) are registered at the Iowa State University, ISU Insect Collection (determinations by J.E. Sublette). However, we failed to find any specimen of $C$. nigrovittatus in the collection of North American Cladotanytarsus examined here (the SUBLETTES' collection), which consists of over 1000 specimens sampled from nearly 200 localities across the USA and Canada (incl. Alaska, Northwest Territories and Nunavut) over a period of some 90 years. The records from the Nearctic region identified on the basis of morphology therefore require comparison of $C$. nigrovittatus with $C$. crassus and several similar species (cf. PUCHALSKI \& GIEKA 2017a, key: couplets 14 \& 15).

Cladotanytarsus nigrovittatus is mainly a boreal inhabitant of freshwater bodies, mostly lakes and slow-flowing rivers (OLIVER \& DILLON 1997; GIŁKA 2011c, present records). Interestingly, it has also been recorded from the Bengal Delta (MAZUMDAR et al. 2000). 


\section{ACKNOWLEDGEMENTS}

We were able to carry out this study thanks to the kindness of Mary and James E. SUBLETTE and entomologists who collected the material. The authors thank Eugenii A. MAKARCHENKO (Vladivostok) and Armin NAMAYANDEH (Toronto) for their comments on the manuscript. This work is part of the junior author's dissertation: "Systematics of North American non-biting midges of the genus Cladotanytarsus KIEFFER" (in progress).

\section{REFERENCES}

Bilyj B., DAVIES I.J. 1989. Descriptions and ecological notes on seven new species of Cladotanytarsus (Chironomidae: Diptera) collected from an experimentally acidified lake. Canadian Journal of Zoology, 67 (4): 948-962.

Brundin L. 1947. Zur Kenntnis der Schwedischen Chironomiden. Arkiv för Zoologi, 39 (3): 1-95.

Dantas G.P.S., GiŁKa W. 2017. New Tanytarsus VAN DER WulP from the Brazilian Amazonia indicate clues to intrageneric relations (Diptera: Chironomidae). Zootaxa, 4294 (2): 281-291.

Ekrem T. 2001. A review of Afrotropical Tanytarsus VAN DER WULP (Diptera: Chironomidae). Tijdschrift voor Entomologie, 144 (1): 5-40.

EKREM T. 2007. A taxonomic revision of the genus Stempellinella (Diptera: Chironomidae). Journal of Natural History, 41: 1367-1465.

EKRem T., Stur E. 2009. A review of the genus Zavrelia (Diptera: Chironomidae). European Journal of Entomology, 106 (1): 119-144.

Ekrem T., Sublette M.F., Sublette J.E. 2003. North American Tanytarsus I. Descriptions and keys to species in the eminulus, gregarius, lugens and mendax species groups (Diptera: Chironomidae). Annals of the Entomological Society of America, 96 (3): 265-328.

GIŁKA W. 2001. A review of Polish Cladotanytarsus KIEFFER (Diptera: Chironomidae) with description of three new species. Polish Journal of Entomology, 70 (4): 307-328.

GıŁKA W. 2002. Tanytarsini (Diptera: Chironomidae) of Poland - a faunistic review. Polish Journal of Entomology, 71 (4): 415-428.

GıŁKA W. 2005. A systematic review of European Stempellina THIENEMANN et BAUSE, 1913 (Diptera: Chironomidae) with description of a new species from Fennoscandia. Annales Zoologici, 55 (3): 413-419.

GıŁKA W. 2008. A rapid technique of producing spatial colour illustrations of diagnostic structures in small dipterans. Dipteron, 24: 8-10.

GıŁKA W. 2011a. Non-biting midges - Chironomidae, tribe Tanytarsini, adult males. Keys for the Identification of Polish Insects. No 177. Part XXVIII, Dipterans - Diptera, Issue 14b. Polskie Towarzystwo Entomologiczne. Biologica Silesiae, Wrocław. (in Polish)

GiŁKA W. 2011b. Six unusual Cladotanytarsus KIEFFER: towards a systematics of the genus and resurrection of Lenziella KIEFFER (Diptera: Chironomidae: Tanytarsini). Zootaxa, 3100: 1-34. 
GıKKA W. 2011c. Analysis of faunistic diversity in chironomids of the tribe Tanytarsini in Europe (Diptera: Chironomidae). Dipteron, 27: 11-31. (in Polish)

GilKa W., PAasivirTa L. 2007. Two new species of the genus Tanytarsus VAN DER WulP (Diptera: Chironomidae) from Fennoscandia. [in:] T. ANDERSEN (ed.). Contributions to the Systematics and Ecology of Aquatic Diptera - A Tribute to Ole A. SÆTHER. The Caddis Press, Columbus, Ohio, $107-113$.

GiŁKa W., ZakrZewska M., Dominiak P., Urbanek A. 2013. Non-biting midges of the tribe Tanytarsini in Eocene amber from the Rovno region (Ukraine): a pioneer systematic study with notes on the phylogeny (Diptera: Chironomidae). Zootaxa, 3736 (5): 569-586.

Goetghebuer M. 1922. Nouveaux matériaux pour l'étude de la fauna de Chironomides de Belgique. Annales de biologie lacustre, 11: 38-62.

HiRvenoja M. 1962. Cladotanytarsus-Arten (Dipt., Chironomidae) aus Finnisch-Lappand. Annales Entomologici Fennici, 28: 173-181.

KYEREMATEN R.A.K., S $Æ$ THER O.A. 2000. A review of Afrotropical Rheotanytarsus THIENEMANN et BAuSE, 1913 (Diptera: Chironomidae). Tijdschrift voor Entomologie, 143 (1-2): 27-69.

LiN X., StUR E., EkREM T. 2017. DNA barcodes and morphology reveal unrecognized species in Chironomidae (Diptera). Insect Systematics \& Evolution, DOI 10.1163/1876312X-00002172, pp. $1-70$.

LiNDEBERG B. 1964. The swarm of males as a unit for taxonomic recognition in the Chironomids (Diptera). Annales Zoologici Fennici, 1 (1): 72-76.

Makarchenko E.A., Makarchenko M.A., Zorina O.V., SergeeVa L.V. 2005. Preliminary data on fauna and taxonomy of Chironomids (Diptera, Chironomidae) of the Russian Far East. Vladimir Ya. Levanidov's Biennial Memorial Meetings, 3: 394-420. (in Russian)

Mazumdar A., Hazra N., Chaudhuri P.K. 2000. New species of Cladotanytarsus KiefFer from the Deltaic region of West Bengal, India (Diptera: Chironomidae). Oriental Insects, 34 (1): 193-202.

Oliver D.R., Dillon M.E. 1997. Chironomids (Diptera: Chironomidae) of the Yukon Arctic North Slope and Herschel Island. [in:] H.V. DANKS, J.A. Downes (eds.) Insects of the Yukon. Biological survey of Canada (terrestrial arthropods), Ottawa, 615-635.

PUChAlSKi M., GiŁKA W. 2017a. Cladotanytarsus KIEFFER (Diptera: Chironomidae): several distinctive species reviewed on the basis of records from Canada and USA. Zootaxa, 4242 (2): 344-358.

PUCHALSKI M., GiŁKA W. 2017b. A new species of Cladotanytarsus (Lenziella) from Oregon supports the systematic concept of the subgenus (Diptera: Chironomidae). Zootaxa, 4268 (4): 573-580.

PUChAlSKi M., PAASIVIRTA L., GiŁKa W. 2018. Cladotanytarsus saetheri sp. nov. and C. gedanicus GıŁKA: Holarctic sibling species (Diptera: Chironomidae). Zootaxa, 4394 (3): 428-436.

PuChalski M., ZAKRZEwSKa M., GitKa W. 2017. Cladotanytarsus KiefFer (Diptera: Chironomidae): exploring the species richness. The $9^{\text {th }}$ Central European Dipterological Conference. Kostelec nad Černými Lesy, Czech Republic. Internet: https://dx.doi.org/10.13140/RG.2.2.12394.62405

Reiss F., Säwedal L. 1981. Key to males and pupae of Palaearctic (excl. Japan) Paratanytarsus THIEnEmann, BAuse 1913, n. comb., with description of three new species (Diptera, Chironomidae). Entomologica scandinavica, Suppl. 15: 73-104. 
RUSE L.P. 2015. Even more chironomid species classifying lake nutrient status. European Journal of Environmental Sciences, 5 (1): 80-85.

SÆTHER O.A. 1971. Four new and unusual Chironomidae (Diptera). Canadian Entomologist 103(12): $1799-1827$.

SÆTHER O.A. 1980. Glossary of chironomid morphology terminology (Diptera: Chironomidae). Entomologica scandinavica, Suppl. 14: 1-51.

SANSEVERINO A. 2006. A review of the genus Tanytarsus VAN DER WulP, 1874 (Insecta, Diptera, Chironomidae) from the Neotropical Region. PhD Thesis, Fakultät für Biologie, LudwigMaximilians-Universität München, München. Intrenet: http://edoc.ub.uni-muenchen.de/4975 (accessed: May 2018).

STUR E., EkREM T. 2006. A revision of West Palaearctic species of the Micropsectra atrofasciata species group (Diptera: Chironomidae). Zoological Journal of the Linnean Society, 146 (2): $165-225$.

WANG X., GuO Y. 2004. A review of the genus Cladotanytarsus KIEFFER from China, with the description of three new species (Diptera: Chironomidae: Tanytarsini). Zootaxa, 750: 1-19.

ZAKRZEWSKA M., GiŁKa W. 2014. The oldest known chironomids of the tribe Tanytarsini (Diptera: Chironomidae) indicate plesiomorphic character states. Geobios, 47 (5): 335-343.

ZAKRZEWSKA M., KRZEMIŃSKI W., GiŁKA W. 2016. Towards the diversity of non-biting midges of the tribe Tanytarsini from Eocene Baltic amber (Diptera: Chironomidae). Palaeontologia Electronica, 19.2.18A: $1-21$.

Zakrzewska M., Stebner F., Puchalski M., Singh H., GiŁka W. 2018. A peculiar leg structure in the first non-biting midge described from Cambay amber, India (Diptera: Chironomidae). Earth and Environmental Science Transactions of the Royal Society of Edinburgh, 107 (2-3): 255-261.

Received: 4 April 2018

Accepted: 8 May 2018 